Brit. F. vener. Dis. (1967), 43, 96.

\title{
SEROLOGICAL TESTS FOR TREPONEMAL DISEASE IN ADULTS IN TWO JAMAICAN COMMUNITIES*
}

\author{
BY \\ M. T. ASHCROFT, W. E. MIALL, K. L. STANDARD, AND A. E. URQUHART \\ From the Medical Research Council Epidemiological Research Unit \\ and the Department of Microbiology, University of the West Indies, Famaica
}

Serological tests for treponemal disease are positive in many Jamaicans. Grant (1956) reported that from 1952 to 1954 of 12,820 men applying for farm employment in the United States, 2,869 (22 per cent.) were reactive in either the Venereal Disease Research Laboratory (VDRL) or the Kolmer-Wassermann tests; the ages were not stated but were probably mostly between 20 and 40 years. This reactivity is mainly caused either by syphilis or by yaws, the latter being a disease which used to be widespread in many rural areas but was not transmitted in Kingston, the capital city. The importance of yaws rather than syphilis as a cause of positive serological tests is suggested by the prevalence in different parishes. For example, 39 per cent. of applicants from the rural parish of St. Thomas, where yaws was once common, were positive, but only 15 per cent. of applicants from Kingston. As, however, considerable migration had taken place into the city, it is not certain how many of those from Kingston had lived in rural areas as children, at the age when they were most likely to be infected with yaws. Chambers (1938) in Jamaica found that the incidence of primary yaws lesions reached its peak between the ages of 5 and 9 years, with the next most frequent incidence between the ages of 6 months and 4 years. Turner and Saunders (1935) reported that 90 per cent. of Jamaican patients with yaws gave a history of infection before the age of 15 years.

This paper records the prevalence of serological reactivity to VDRL and Reiter protein complement-fixation (RPCF) tests in surveys of representative groups of adults aged 35-64 years living in a rural area, Lawrence Tavern, where yaws had once been prevalent and also in a population in August Town in the suburbs of Kingston, where a

\footnotetext{
* Received for publication September 16, 1966.
}

positive test among those born and brought up in the city would suggest syphilis rather than yaws.

\section{The Communities}

(1) The Rural Population The rural population lived in the parish of St. Andrew, 16 miles from Kingston, the centre of the area being the village of Lawrence Tavern. The people were mainly of African descent with a small and variable amount of European ancestry. They can best be summarized as sturdy, independent peasants with a distinctive Jamaican culture; nearly all are poor, but few are destitute. Conjugal ties are weak and sexual permissiveness is usually accepted and tolerated (see Clarke, 1957; Henriques, 1957; Blake, 1961). The main occupation is the cultivation of small plots of vegetables and fruits for home consumption or for sale in Kingston markets. The density of population is about 600 per square mile. The average annual rainfall lies between 80 and 100 inches; rainy seasons are not usually well marked, but maximum periods of rainfall tend to occur in October and May. The mean maximum and minimum temperatures at 1,000 feet above sea level, the average altitude, are about $83^{\circ}$ and $69^{\circ} \mathrm{F}$. The underlying geological formation is either igneous or undifferentiated metamorphic rocks. Meteorology and geology are relevant to the study of yaws in Jamaica, because in districts with a high rainfall and impermeable rocks, such as in Lawrence Tavern, yaws used to be common, whereas it was rarer where the rainfall was less and in the limestone areas which form a considerable part of the island (Chambers, 1938).

Most of the population were born and spent their childhood in the area or in its vicinity and as the youngest subjects were 35 years old at the time of the survey in 1962, all would have been children at a time when yaws was very common 
with a strong possibility of infection. After 1940 several surveys followed by treatment campaigns were carried out in the area and the incidence of yaws diminished, so that by 1955 the disease had almost completely disappeared; occasional cases among young children are now seen.

The main purpose of the survey in 1962 was to investigate the prevalence of certain heart conditions, as reported by Fodor, Miall, Standard, Fefjar, and Stuart (1964), but it has been thought worthwhile to publish the results of tests for treponemal disease separately.

A total population of about 7,500 was enumerated in a defined geographical area by private census. Each person was allocated a card and, after sorting according to age and sex, the cards were sampled by using random numbers to select 100 subjects of each sex in each of the three decades, $33-44,45-54$, and $55-64 ; 600$ people were thus selected for examination. Table I shows the completion rates for VDRL and RPCF tests which were slightly lower than the response rates as a few people refused venepuncture.

(2) The Suburban Population August Town is a suburb on the outskirts of Kingston, close to the University of the West Indies. The people are also mainly of African origin and are employed in a variety of lowly-paid occupations; their cash income and general standards of living are higher than in Lawrence Tavern. The climate is somewhat hotter and drier. No record is known of any local transmission of yaws.

From responses to questions asked when they attended the survey clinic, they were divided into those born and brought up in Kingston or its suburbs and those born elsewhere. The latter were sub-divided into those who had lived in hilly rural areas until the age of at least 15 years before moving into Kingston and those who had come to the city before the age of 15 years or who had lived mainly in lowland areas. These questions were asked for the purpose of cardiovascular research but are relevant to the likelihood of yaws infection; those born and bred in Kingston would not be expected to have experienced yaws. [Gourlay and Marsh (1965) have recently described an exceptional outbreak involving four children in the neighbouring suburban community of Hermitage; the disease was probably imported by one of the patients who had been infected in a rural area.] Those living in hilly districts until at least the age of 15 would be more likely to have been infected with yaws than the others, as the disease was, in general, more prevalent in the hills.

A census was made of the population and a survey of all persons aged 35-64 was undertaken in 1965. The completion rates for the VDRL and RPCF tests are shown in Table I.

\section{Techniques}

In both surveys, each person in the sample was given an explanation of the investigations to be carried out and appointments were made for about fifteen persons daily to be transported to a central clinic. After completion of a questionnaire and general medical examination, an electrocardiogram was taken and, in the August Town survey, a radiograph of the chest; venous blood was obtained from the arm. In Lawrence Tavern, but unfortunately not in August Town, subjects were asked if they had been infected with yaws; men but not women were asked if they had suffered from venereal disease.

Sera were examined at the Department of Microbiology, University of the West Indies by the VDRL and RPCF tests, using the one-fifth Kolmer technique with antigen supplied by Difco Laboratories as described by the U.S. Communicable

TABLE I

PROPORTION OF POPULATIONS TESTED

\begin{tabular}{|c|c|c|c|c|c|c|c|}
\hline \multirow[b]{2}{*}{ Sex } & \multirow[b]{2}{*}{ Age (yrs) } & \multicolumn{3}{|c|}{ Lawrence Tavern } & \multicolumn{3}{|c|}{ August Town } \\
\hline & & $\begin{array}{c}\text { Total } \\
\text { Population }\end{array}$ & Sample & $\begin{array}{l}\text { No. } \\
\text { Tested }\end{array}$ & $\begin{array}{c}\text { Total } \\
\text { Population }\end{array}$ & $\begin{array}{l}\text { No. } \\
\text { Tested }\end{array}$ & $\begin{array}{c}\text { Percentage } \\
\text { Tested }\end{array}$ \\
\hline \multirow[t]{2}{*}{ Female } & $\begin{array}{l}35-44 \\
45-54 \\
55-64\end{array}$ & $\begin{array}{l}371 \\
323 \\
270\end{array}$ & $\begin{array}{l}100 \\
100 \\
100\end{array}$ & $\begin{array}{l}86 \\
81 \\
86\end{array}$ & $\begin{array}{r}141 \\
105 \\
84\end{array}$ & $\begin{array}{r}123 \\
96 \\
71\end{array}$ & $\begin{array}{l}87 \cdot 2 \\
91 \cdot 4 \\
84 \cdot 5\end{array}$ \\
\hline & Total & 964 & 300 & 253 & 330 & 290 & $87 \cdot 9$ \\
\hline \multirow[t]{2}{*}{ Male } & $\begin{array}{l}35-44 \\
45-54 \\
55-64\end{array}$ & $\begin{array}{l}274 \\
284 \\
262\end{array}$ & $\begin{array}{l}100 \\
100 \\
100\end{array}$ & $\begin{array}{l}81 \\
81 \\
85\end{array}$ & $\begin{array}{r}118 \\
96 \\
53\end{array}$ & $\begin{array}{l}93 \\
78 \\
41\end{array}$ & $\begin{array}{l}78 \cdot 8 \\
81 \cdot 3 \\
77 \cdot 4\end{array}$ \\
\hline & Total & 820 & 300 & 247 & 267 & 212 & $79 \cdot 4$ \\
\hline
\end{tabular}


Disease Center (1962). Letters were written to all patients with positive reactions advising them to attend a clinic for treatment.

\section{Results}

The results are shown in Tables II and III and in the Figure (opposite).
The sera of 37 per cent. of the men and 32 per cent. of the women were reactive or weakly reactive by VDRL tests in August Town and of 50 per cent. of men and 40 per cent. of women in Lawrence Tavern. The pattern of results given by the RPCF tests was similar but a slightly higher proportion was reactive.

TABLE II

VDRL AND RPCF TEST RESULTS IN MEN

\begin{tabular}{|c|c|c|c|c|c|c|c|c|c|c|c|}
\hline \multirow{3}{*}{$\begin{array}{c}\text { Age } \\
\text { (yrs) }\end{array}$} & \multirow{3}{*}{\multicolumn{2}{|c|}{ Area }} & \multicolumn{6}{|c|}{ VDRL Test } & \multicolumn{3}{|c|}{ RPCF Test } \\
\hline & & & \multirow{2}{*}{$\begin{array}{l}\text { No. of } \\
\text { Subjects }\end{array}$} & \multirow{2}{*}{$\begin{array}{l}\text { Weakly } \\
\text { Reactive }\end{array}$} & \multicolumn{4}{|c|}{ Dilutions of Reactive Tests } & \multirow{2}{*}{$\begin{array}{l}\text { No. of } \\
\text { Subjects* }\end{array}$} & \multicolumn{2}{|c|}{ Reactive } \\
\hline & & & & & $\begin{array}{c}1: 1 \\
\text { and } 1: 2\end{array}$ & $\begin{array}{c}1: 4 \\
\text { and } 1: 8\end{array}$ & $1: 16+$ & $\begin{array}{c}\text { Per cent. } \\
\text { WR } \\
\text { and } R\end{array}$ & & No. & Per cent. \\
\hline $\begin{array}{l}35-44 \\
45-54 \\
55-64\end{array}$ & \multirow{4}{*}{$\begin{array}{l}\text { August } \\
\text { Town }\end{array}$} & $\begin{array}{l}\text { Born in } \\
\text { Kingston }\end{array}$ & $\begin{array}{r}23 \\
17 \\
8\end{array}$ & $\begin{array}{l}3 \\
2 \\
0\end{array}$ & $\begin{array}{l}0 \\
1 \\
1\end{array}$ & $\begin{array}{l}2 \\
1 \\
0\end{array}$ & $\begin{array}{l}\mathbf{0} \\
\mathbf{0} \\
\mathbf{0}\end{array}$ & $\begin{array}{l}22 \\
24 \\
13\end{array}$ & $\begin{array}{r}22 \\
16 \\
8\end{array}$ & $\begin{array}{l}7 \\
6 \\
1\end{array}$ & $\begin{array}{l}32 \\
38 \\
13\end{array}$ \\
\hline $\begin{array}{l}35-44 \\
45-54 \\
55-64\end{array}$ & & $\begin{array}{l}\text { Mixed } \\
\text { Group }\end{array}$ & $\begin{array}{l}36 \\
36 \\
21\end{array}$ & $\begin{array}{l}7 \\
7 \\
4\end{array}$ & $\begin{array}{l}2 \\
6 \\
1\end{array}$ & $\begin{array}{l}1 \\
0 \\
1\end{array}$ & $\begin{array}{l}1 \\
1 \\
2\end{array}$ & $\begin{array}{l}36 \\
39 \\
38\end{array}$ & $\begin{array}{l}36 \\
35 \\
19\end{array}$ & $\begin{array}{r}13 \\
16 \\
7\end{array}$ & $\begin{array}{l}36 \\
46 \\
37\end{array}$ \\
\hline $\begin{array}{l}35-44 \\
45-54 \\
55-64\end{array}$ & & $\begin{array}{l}\text { Lived in Hills } \\
\text { until } 15 \\
\text { years old }\end{array}$ & $\begin{array}{l}34 \\
25 \\
12\end{array}$ & $\begin{array}{l}6 \\
5 \\
2\end{array}$ & $\begin{array}{l}4 \\
5 \\
2\end{array}$ & $\begin{array}{l}3 \\
3 \\
1\end{array}$ & $\begin{array}{l}0 \\
3 \\
1\end{array}$ & $\begin{array}{l}38 \\
64 \\
50\end{array}$ & $\begin{array}{l}33 \\
24 \\
11\end{array}$ & $\begin{array}{r}17 \\
13 \\
4\end{array}$ & $\begin{array}{l}52 \\
54 \\
36\end{array}$ \\
\hline $\begin{array}{l}35-44 \\
45-54 \\
55-64\end{array}$ & & Total & $\begin{array}{l}93 \\
78 \\
41\end{array}$ & $\begin{array}{r}16 \\
14 \\
6\end{array}$ & $\begin{array}{r}6 \\
12 \\
4\end{array}$ & $\begin{array}{l}6 \\
4 \\
2\end{array}$ & $\begin{array}{l}1 \\
4 \\
3\end{array}$ & $\begin{array}{r}31 \\
44 \\
37\end{array}$ & $\begin{array}{l}91 \\
75 \\
38\end{array}$ & $\begin{array}{l}37 \\
35 \\
12\end{array}$ & $\begin{array}{l}41 \\
47 \\
32\end{array}$ \\
\hline Total & \multicolumn{2}{|c|}{ August Town } & 212 & 36 & 22 & 12 & 8 & 37 & 204 & 84 & 41 \\
\hline $\begin{array}{l}35-44 \\
45-54 \\
55-64\end{array}$ & \multicolumn{2}{|c|}{ Lawrence Tavern } & $\begin{array}{l}81 \\
81 \\
85 \\
\end{array}$ & $\begin{array}{l}16 \\
24 \\
22 \\
\end{array}$ & $\begin{array}{l}11 \\
12 \\
10\end{array}$ & $\begin{array}{r}5 \\
5 \\
10 \\
\end{array}$ & $\begin{array}{l}2 \\
3 \\
5\end{array}$ & $\begin{array}{l}42 \\
54 \\
54 \\
\end{array}$ & $\begin{array}{l}81 \\
76 \\
83 \\
\end{array}$ & $\begin{array}{l}42 \\
42 \\
49 \\
\end{array}$ & $\begin{array}{l}52 \\
55 \\
59 \\
\end{array}$ \\
\hline Total & \multicolumn{2}{|c|}{ Lawrence Tavern .. } & 247 & 62 & 33 & 20 & 9 & 50 & 240 & 133 & 55 \\
\hline
\end{tabular}

* The number of RPCF was less than the VDRL tests because fifteen were anticomplementary.

TABLE III

VDRL AND RPCF TEST RESULTS IN WOMEN

\begin{tabular}{|c|c|c|c|c|c|c|c|c|c|c|c|}
\hline \multirow{3}{*}{$\begin{array}{c}\text { Age } \\
\text { (yrs) }\end{array}$} & & \multirow{3}{*}{ Area } & \multicolumn{6}{|c|}{ VDRL Test } & \multicolumn{3}{|c|}{ RPCF Test } \\
\hline & & & \multirow{2}{*}{$\begin{array}{l}\text { No. of } \\
\text { Subjects }\end{array}$} & \multirow{2}{*}{$\begin{array}{l}\text { Weakly } \\
\text { Reactive }\end{array}$} & \multicolumn{4}{|c|}{ Dilutions of Reactive Tests } & \multirow{2}{*}{$\begin{array}{c}\text { No. of } \\
\text { Subjects* }\end{array}$} & \multicolumn{2}{|c|}{ Reactive } \\
\hline & & & & & $\begin{array}{c}1: 1 \\
\text { and } 1: 2\end{array}$ & $\begin{array}{c}1: 4 \\
\text { and } 1: 8\end{array}$ & $1: 16+$ & $\begin{array}{l}\text { Per cent. } \\
\text { WR } \\
\text { and } R\end{array}$ & & No. & Per cent. \\
\hline $\begin{array}{l}35-44 \\
45-54 \\
55-64\end{array}$ & \multirow{4}{*}{$\underset{\text { Town }}{\text { August }}$} & $\begin{array}{l}\text { Born in } \\
\text { Kingston }\end{array}$ & $\begin{array}{l}30 \\
25 \\
17\end{array}$ & $\begin{array}{l}0 \\
1 \\
1\end{array}$ & $\begin{array}{l}2 \\
1 \\
0\end{array}$ & $\begin{array}{l}\mathbf{0} \\
\mathbf{0} \\
\mathbf{2}\end{array}$ & $\begin{array}{l}2 \\
0 \\
0\end{array}$ & $\begin{array}{r}13 \\
8 \\
18\end{array}$ & $\begin{array}{l}30 \\
25 \\
17\end{array}$ & $\begin{array}{l}7 \\
5 \\
2\end{array}$ & $\begin{array}{l}23 \\
20 \\
12\end{array}$ \\
\hline $\begin{array}{l}35-44 \\
45-54 \\
55-64\end{array}$ & & $\begin{array}{l}\text { Mixed } \\
\text { Group }\end{array}$ & $\begin{array}{l}58 \\
46 \\
42\end{array}$ & $\begin{array}{r}8 \\
11 \\
8\end{array}$ & $\begin{array}{l}7 \\
2 \\
9\end{array}$ & $\begin{array}{l}0 \\
1 \\
1\end{array}$ & $\begin{array}{l}1 \\
2 \\
1\end{array}$ & $\begin{array}{l}28 \\
35 \\
45\end{array}$ & $\begin{array}{l}57 \\
44 \\
40\end{array}$ & $\begin{array}{l}18 \\
20 \\
18\end{array}$ & $\begin{array}{l}31 \\
45 \\
45\end{array}$ \\
\hline $\begin{array}{l}35-44 \\
45-54 \\
55-64\end{array}$ & & $\begin{array}{l}\text { Lived in Hills } \\
\text { until } 15 \\
\text { years old }\end{array}$ & $\begin{array}{l}35 \\
25 \\
12\end{array}$ & $\begin{array}{l}6 \\
5 \\
5\end{array}$ & $\begin{array}{l}3 \\
\mathbf{2} \\
1\end{array}$ & $\begin{array}{l}6 \\
4 \\
0\end{array}$ & $\begin{array}{l}1 \\
1 \\
0\end{array}$ & $\begin{array}{l}46 \\
48 \\
50\end{array}$ & $\begin{array}{l}34 \\
25 \\
11\end{array}$ & $\begin{array}{r}17 \\
12 \\
4\end{array}$ & $\begin{array}{l}50 \\
48 \\
36\end{array}$ \\
\hline $\begin{array}{l}35-44 \\
45-54 \\
55-64\end{array}$ & & Total & $\begin{array}{r}123 \\
96 \\
71\end{array}$ & $\begin{array}{l}14 \\
17 \\
14\end{array}$ & $\begin{array}{r}12 \\
5 \\
10\end{array}$ & $\begin{array}{l}\mathbf{6} \\
\mathbf{5} \\
\mathbf{3}\end{array}$ & $\begin{array}{l}4 \\
3 \\
1\end{array}$ & $\begin{array}{l}30 \\
31 \\
39\end{array}$ & $\begin{array}{r}121 \\
94 \\
68\end{array}$ & $\begin{array}{l}42 \\
37 \\
24\end{array}$ & $\begin{array}{l}35 \\
39 \\
35\end{array}$ \\
\hline Total & August Tow & . & 290 & 45 & 27 & 14 & 8 & 32 & 283 & 103 & 36 \\
\hline $\begin{array}{l}35-44 \\
45-54 \\
55-64\end{array}$ & \multicolumn{2}{|c|}{ Lawrence Tavern } & $\begin{array}{l}86 \\
81 \\
86\end{array}$ & $\begin{array}{l}15 \\
21 \\
18\end{array}$ & $\begin{array}{r}5 \\
12 \\
15\end{array}$ & $\begin{array}{l}2 \\
3 \\
3\end{array}$ & $\begin{array}{l}0 \\
3 \\
5\end{array}$ & $\begin{array}{l}26 \\
48 \\
48\end{array}$ & $\begin{array}{l}86 \\
80 \\
84\end{array}$ & $\begin{array}{l}32 \\
41 \\
40\end{array}$ & $\begin{array}{l}37 \\
51 \\
48\end{array}$ \\
\hline Total & \multicolumn{2}{|c|}{ Lawrence Tavern . . } & 253 & 54 & 32 & 8 & 8 & 40 & 250 & 113 & 45 \\
\hline
\end{tabular}

* The number of RPCF was less than the VDRL tests because ten were anticomplementary. 


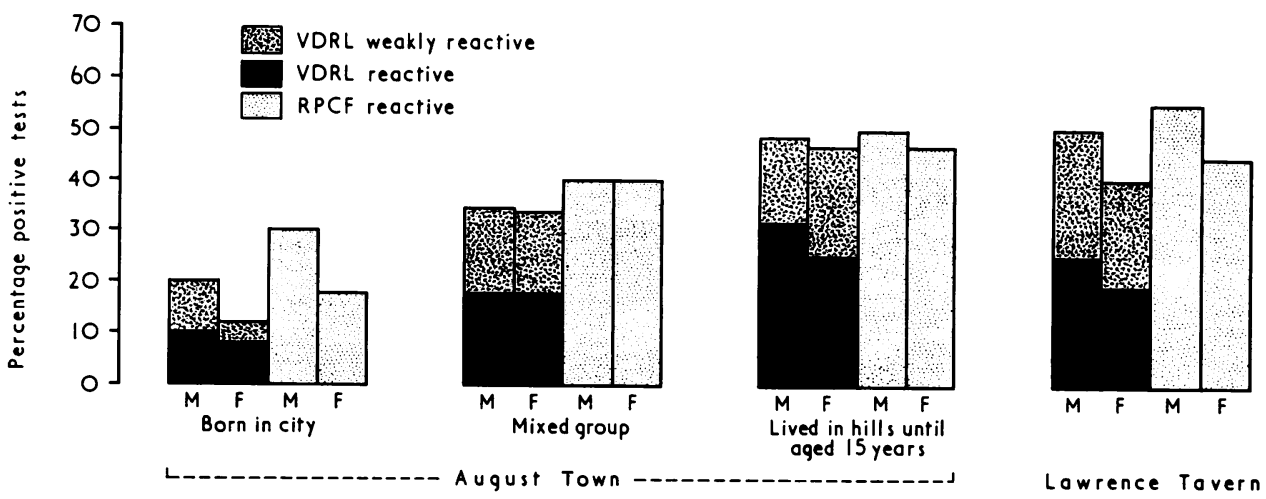

FIGURE.-Results of VDRL and RPCF tests in different populations.

One of the most noticeable features of the results is that considerably fewer August Town subjects who were born in Kingston were positive in the tests $(20$ per cent. of men and 12 per cent. of women in the VDRL tests) than those who had lived in hilly areas and come to the urban area after the age of 15 years ( 49 per cent. of men and 47 per cent. of women); the serological reactivity of the latter resembled that of Lawrence Tavern where 50 per cent. of men and 40 per cent. of women were positive in the VDRL tests. The other group in August Town who may have migrated from rural areas when young or who may have lived in lowland rural areas occupied an intermediate position. In general, a higher proportion of males than of females was positive but differences were small. No consistent difference existed between age groups.

The pattern of results of the VDRL and RPCF tests was similar although not identical (Table IV). 35 per cent. of the total population were reactive in both tests; 48 per cent. were reactive in either one of the tests or both.

TABLE IV

COMPARISON OF THE RESULTS OF VDRL AND RPCF TESTS

\begin{tabular}{|c|c|c|c|c|}
\hline \multirow[b]{2}{*}{ VDRL } & \multicolumn{4}{|c|}{ RPCF } \\
\hline & Reactive & Negative & $\begin{array}{l}\text { Anti- } \\
\text { comple- } \\
\text { mentary }\end{array}$ & Total \\
\hline $\begin{array}{l}\text { Reactive or } \\
\text { weakly reactive }\end{array}$ & 347 & 33 & 18 & 398 \\
\hline Negative & 86 & 511 & 7 & 604 \\
\hline Total .. & 433 & 544 & 25 & 1,002 \\
\hline
\end{tabular}

In order to test the reproducibility of the results, 68 specimens taken during the August Town survey were split into two, without the knowledge of the laboratory, before being tested. The results (Tables V and VI) show that the end points of the tests were not precise but very rarely differed by more than one dilution.

\section{TABLE V}

COMPARISON OF THE RESULTS OF THE VDRL TEST IN 65 SPLIT SPECIMENS*

\begin{tabular}{|c|c|c|c|c|c|c|c|}
\hline & & \multirow[b]{2}{*}{ Negative } & \multicolumn{5}{|c|}{ Dilutions of Reactive Tests } \\
\hline & & & $\begin{array}{c}\text { Weakly } \\
\text { Reactive }\end{array}$ & 1 & 2 & 4 & 8 \\
\hline \multicolumn{2}{|c|}{ Negative } & 35 & 2 & 1 & & & \\
\hline \multirow{5}{*}{$\begin{array}{c}\text { Dilutions } \\
\text { of } \\
\text { Reactive } \\
\text { Tests }\end{array}$} & $\begin{array}{l}\text { Weakly } \\
\text { Reactive }\end{array}$ & 3 & 12 & 1 & & & \\
\hline & 1 & & 1 & 2 & & & \\
\hline & 2 & & & 2 & & 1 & \\
\hline & 4 & & & 1 & 2 & & \\
\hline & 8 & & & & & 1 & 1 \\
\hline
\end{tabular}

* The results of three tests reactive at dilutions above $1: 8$ have been omitted; one pair of split specimens gave identical results and two pairs differed by one dilution.

TABLE VI

COMPARISON OF THE RESULTS OF THE RPCF TEST IN 68 SPLIT SPECIMENS

\begin{tabular}{ll|c|c|c}
\hline & Negative & Reactive & $\begin{array}{c}\text { Anti- } \\
\text { complementary }\end{array}$ \\
\hline Negative r . & 30 & 3 & - \\
\hline Reactive r . & 3 & 30 & - \\
\hline $\begin{array}{l}\text { Anti- } \\
\text { complementary }\end{array}$ & - & 1 & 1 \\
\hline
\end{tabular}




\section{Yaws in Jamaica}

\section{Discussion}

Some knowledge of the present and past status of yaws and syphilis in Jamaica is necessary before the results can be understood. The history of yaws in Jamaica has been described by Gentle (1965). The disease was brought to the island from Africa but was partially controlled by the isolation of cases in "yaw huts" on estates. It probably became more common following the emancipation and the movement of people from estates to independent settlement in the hills. Because of a continuing high incidence a Yaws Commission was set up in 1932 for research and control.

The epidemiology was studied and the distribution and prevalence of yaws throughout the island was mapped (Chambers, 1937, 1938; Saunders, Chambers, and Rerrie, 1936; Saunders, Kumm, and Rerrie, 1936; Turner, 1936; Turner and Saunders, 1935). It was shown that Hippelates pallipes, a common insect pest, might be a vector (Kumm, 1935a, b; Kumm and Turner, 1936; Kumm, Turner, and Peat, 1935).

Mobile Yaws Units were set up to survey badly-affected districts and to arrange treatment. Later these Units assumed other public health duties, but yaws was the chief problem with which they were concerned and many thousands of cases were treated annually. The incidence of yaws began to decline rapidly about 1953 and the Units were disbanded in 1957. The decline was due partly to a rising standard of living and partly to the great advance made by the introduction of one intramuscular injection of penicillin as an effective treatment; previously it had been necessary to give repeated intravenous doses of salvarsan or some related arsenic or bismuth compound and many patients defaulted before treatment was completed.

No mass eradication programme has been undertaken in Jamaica, as was done in neighbouring Haiti in 1951 and in some of the Windward Islands more recently. Campaigns were carried out locally in areas in which a high incidence has been noted but only clinically suspicious cases and their contacts were treated.

The number of cases of yaws reported has recently appeared to increase and in 1963 Gentle (1965) carried out an island-wide survey. Public health inspectors and other field workers requested all persons with suspicious skin lesions to attend special clinics, and 673 cases, 265 of which were infectious, were diagnosed in 5,740 persons examined at 106 different clinic sessions. The patients were scattered throughout the island, infections usually being commoner in those areas where the disease was prevalent in the past.

In some localities the disease may be more common than might appear from the number of recognized cases. Ashcroft, Urquhart, and Gentle (1965) found that, in a school in the parish of St. Mary, 28 per cent. of pupils aged from 7 to 15 years were reactive or weakly reactive in the VDRL test and 34 per cent. were reactive in the RPCF test; comparable figures in a Kingston school were 2 per cent. and 4 per cent. respectively. Considerable unrecognized infection must have occurred in St. Mary because neither a history nor signs of yaws were obtained from many children whose sera were positive.

\section{Syphilis in Jamaica}

Little is known of the history and prevalence of syphilis in Jamaica and the position is confusing even to-day. Serological tests to which so much attention is attached in temperate climates afford little confirmation that a suspected lesion is syphilitic because so high a proportion of the population is reactive as a result of yaws. Positive tests are sometimes erroneously ascribed to syphilis, and "bad blood", which is a well-known term, is often a source of unnecessary inconvenience and distress.

The statistics of new cases of venereal disease seen at public health clinics from 1960 to 1965 are shown in Table VII (opposite). This list is not, of course, comprehensive for all Jamaica, because an unknown number of cases do not attend clinics. Patients with tertiary lesions are more likely to be seen in hospitals.

Most physicians agree that congenital syphilis is rare and that benign tertiary syphilis is uncommon. Cardiovascular syphilis occurs but its true prevalence is unknown. Many patients with gross aortic dilatation and aortic incompetence are admitted to hospitals (Tulloch, 1958). Autopsy studies show the classical signs of syphilis in some, but in others the pathology is not clear. Stuart, Miall, Tulloch, and Christian (1962) found that in Lawrence Tavern both aortic dilatation and aortic incompetence were associated with hypertension rather than with positive treponemal serological tests. They suggested that the association with hypertension may often be missed because, by the time patients are admitted to hospital, the hypertension is masked by severe aortic valvular disease. If the serological tests are positive the condition may be wrongly diagnosed as syphilitic. 
TABLE VII

NEW CASES ATTENDING VENEREAL DISEASE CLINICS IN JAMAICA

\begin{tabular}{|c|c|c|c|c|c|c|c|c|c|c|c|c|}
\hline Year .. & $\cdots$ & .. & $\cdots$ & $\cdots$ & $\cdots$ & $\cdots$ & 1960 & 1961 & 1962 & 1963 & 1964 & 1965 \\
\hline \multirow{7}{*}{\multicolumn{2}{|c|}{ Syphilis }} & \multicolumn{2}{|c|}{ Primary } & $\cdots$ & $\cdots$ & $\cdots$ & 350 & 289 & 176 & 190 & 97 & 140 \\
\hline & & \multicolumn{2}{|c|}{ Secondary } & .. & . & .. & 146 & 136 & 162 & 146 & 96 & 102 \\
\hline & & \multicolumn{2}{|c|}{ Early latent } & . & .. & . & 2,484 & 908 & 866 & 685 & 420 & 566 \\
\hline & & \multicolumn{2}{|c|}{ Late latent } & $\cdots$ & . & .. & 1,274 & 449 & 382 & 345 & 293 & 231 \\
\hline & & \multicolumn{3}{|c|}{ Benign tertiary } & .. & $\cdots$ & 13 & 19 & 11 & 11 & 15 & 4 \\
\hline & & \multicolumn{2}{|c|}{ Congenital } & . & .. & .. & 61 & 69 & 30 & 27 & 15 & 24 \\
\hline & & \multicolumn{3}{|c|}{ Neurosyphilis } & .. & .. & 13 & 44 & 22 & 21 & 4 & 3 \\
\hline \multicolumn{2}{|c|}{ Lymphogranuloma } & a ven & ereum & . & $\cdots$ & .. & 481 & 435 & 518 & 376 & 251 & 164 \\
\hline \multicolumn{3}{|c|}{ Granuloma inguinale } & . & . & . & . & 143 & 137 & 132 & 89 & 55 & 165 \\
\hline Chancroid & $\cdots$ & $\cdots$ & .. & $\cdots$ & $\cdots$ & . & 163 & 171 & 151 & 116 & 63 & 75 \\
\hline \multirow{2}{*}{\multicolumn{2}{|c|}{ Gonorrhoea }} & New & cases & $\cdots$ & $\cdots$ & .. & 22,551 & 22,223 & 22,908 & 18,083 & 16,353 & 17,626 \\
\hline & & \multicolumn{3}{|c|}{ Re-infections .. } & . & .. & 14,950 & 16,443 & 12,074 & 12,999 & 14,132 & 15,061 \\
\hline
\end{tabular}

The incidence and the pattern of neurosyphilis in Jamaica is also difficult to estimate. Tabes dorsalis is rarely seen and general paresis is less common than might be expected, although a number of cases may be missed (Cruickshank, personal communication). A puzzling condition known as Jamaican neuropathy is more prevalent. The clinical features, which are usually of insidious onset, vary, but include spastic paraplegia, a posterior column type of sensory loss, retrobulbar neuropathy, nerve deafness, and selective muscle wasting. The cases have been arbitrarily divided into spastic and ataxic groups. The aetiology has been discussed by Cruickshank (1956), Montgomery (1960), Cruickshank, Montgomery, and Spillane (1961), Montgomery, Cruickshank, Robertson, and McMenemy (1964), and Rodgers (1965). Suspicion fell initially on possible nutritional deficiencies because the cerebrospinal fluid was usually negative to treponemal tests and the response to penicillin was poor. More recently, however, more attention has been paid to the possibility of treponemata being an underlying cause of the spastic syndrome which resembles in many ways Erb's syphilitic spinal paralysis. Although the cerebrospinal fluid in the great majority of cases is negative in routine tests for treponemal disease, it may contain abnormal amounts of cells and protein, and at autopsy a chronic meningomyelitis with damage to the long tracts of the spinal cord has been found. A spectrum of appearances seems to exist between undoubted cases of spinal syphilis and those of this neuropathy. Understanding is not yet complete, however, as there are a number of unexplained features; Montgomery and his colleagues (1964) have suggested that, besides treponemata, several other factors, including nutritional deficiencies and toxins, may act either separately or in combination to produce similar lesions of vulnerable tracts of the nervous system.

Various explanations could account for the apparent rarity and the different appearances of neurosyphilis in tropical compared with temperate countries. Differences in racial susceptibility may play some part, because tabes dorsalis, and to a lesser extent general paresis, seems to be rare in Africa and also less common in Negroes than among whites in the United States (Turner, 1930). Another characteristic of the tropics is that many people exposed to syphilis may have been infected with yaws in childhood and it is not known whether the appearances of the tertiary stage would be modified, if not prevented, if syphilis were contracted after a mild or treated yaws infection. A third possibility is that, in parts of the tropics, Treponema pallidum is less neurotropic than elsewhere. Such a difference is not improbable. Hudson (1965) has suggested that pinta, yaws, endemic syphilis, and venereal syphilis are merely adaptations of one treponemal species to different ecologies. If the variability of the spirochaete is such that it can cause such strikingly different diseases, then it would be logical to expect that there would be considerable variations within one disease. There can be little doubt that the virulence of syphilis has changed. Although it is controversial whether venereal syphilis existed in Europe before 
the return of Columbus from the West Indies, it is almost certain that his sailors introduced a very virulent form which later became more chronic, presumably because of an evolutionary change in the spirochaete.

\section{Causes of Sero-reactivity in Jamaica}

The interpretation of differences in the serological reactivity of our survey populations must be somewhat speculative because we have no information other than that of a general and not very reliable nature on the incidence and previous treatment of yaws and syphilis. In addition, a positive test does not distinguish between active, latent, or cured treponemal infections. With some reservations because of this lack of information, we believe that the most likely explanation of the high prevalence of positive tests in Lawrence Tavern and in those in August Town who had spent their childhood in hilly rural areas is yaws infection, cured either spontaneously or by treatment.

This belief is supported in Lawrence Tavern subjects by the relationship between a history of yaws and serological results (Table VIII). A history of yaws was given by 47.8 per cent. of men and $32 \cdot 1$ per cent. of women; $65 \cdot 7$ per cent. of men and $58 \cdot 3$ per cent. of women with a yaws history were positive in the VDRL tests compared with 34.3 per cent. of men and 31.6 per cent. of women who did not think or did not know they had had an infection. These figures strongly suggest that yaws is the most important cause of the serological reactivity especially as a history of this disease is not reliable; subjects may have forgotten or may have never known they had been infected or, if they did know, might be unwilling to admit to having suffered from a condition which carried a social stigma.
Only two men gave a history suggestive of syphilis, but 36 per cent. of men said they had suffered from gonorrhoea. The prevalence of positive serological tests amongst them was less than in those who gave no history of gonorrhoea. These results would be surprising if venereal infection was a major cause of positive tests for treponemal disease, because those infected with gonorrhoea would be expected to have a higher risk of contracting syphilis.

Sero-reactivity in those who have lived in Kingston since birth is probably due to syphilis in most cases, but we do not know whether the infections were cured, latent, or active. It is, however, possible that a few of those classified as born and brought up in Kingston may have visited rural areas for a short time in childhood and there have acquired yaws.

The proportion of persons in the population who are found to be reactive to tests for treponemal disease will, of course, depend on the sensitivity and specificity of the tests being used. One example of different results given by different tests is afforded by an investigation in Lawrence Tavern in 1960 (data of Stuart and others, 1961). Three serological tests were performed on each of 357 men and women aged 35-64 years; 44 per cent. were positive in the VDRL, 26 per cent. in the Price's precipitation reaction, and 16 per cent. in the Wassermann reaction. Another example in Jamaica is afforded by a survey of school children by Ashcroft and others (1965). At one school where 244 pupils were examined, 4 per cent. were reactive or weakly reactive in the VDRL test and 19 per cent. in the RPCF test. In contrast, at a school in Kingston, the VDRL test was reactive in 2 per cent. and the RPCF test in 4 per cent. of 252 pupils. No reason other than that of past differences in exposure to yaws infection, which the

TABLE VIII

PERCENTAGE SERO-REACTIVITY BY VDRL AND RPCF TESTS* OF SUBJECTS WITH HISTORY OF YAWS AND GONORRHOEA

\begin{tabular}{|c|c|c|c|c|c|c|c|c|c|c|c|c|}
\hline \multirow{2}{*}{$\frac{\text { Sex . . }}{\text { History }}$} & \multirow{2}{*}{$\cdots$} & \multirow{2}{*}{$\cdots$} & \multirow{2}{*}{$\cdots$} & \multirow{2}{*}{$\begin{array}{l}\cdots \\
\cdots\end{array}$} & \multirow{2}{*}{$\begin{array}{l}\cdots \\
\cdots\end{array}$} & \multirow{2}{*}{ 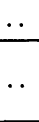 } & \multicolumn{4}{|c|}{ Male } & \multicolumn{2}{|c|}{ Female } \\
\hline & & & & & & & $\begin{array}{c}\text { History } \\
\text { of } \\
\text { Gonorrhoea }\end{array}$ & $\begin{array}{c}\text { No History } \\
\text { of } \\
\text { Gonorrhoea }\end{array}$ & $\begin{array}{l}\text { History } \\
\text { of } \\
\text { Yaws }\end{array}$ & $\begin{array}{c}\text { No History } \\
\text { of } \\
\text { Yaws }\end{array}$ & $\begin{array}{c}\text { History } \\
\text { of } \\
\text { Yaws }\end{array}$ & $\begin{array}{c}\text { No History } \\
\text { of } \\
\text { Yaws }\end{array}$ \\
\hline \multirow{2}{*}{\multicolumn{2}{|c|}{ VDRL }} & \multicolumn{3}{|c|}{ Positive, per cent. } & $\cdots$ & $\cdots$ & $42 \cdot 0$ & $56 \cdot 6$ & $65 \cdot 7$ & $38 \cdot 1$ & $58 \cdot 3$ & $31 \cdot 6$ \\
\hline & & \multicolumn{3}{|c|}{ Negative, per cent. } & $\cdots$ & $\cdots$ & $58 \cdot 0$ & $43 \cdot 4$ & $34 \cdot 3$ & $61 \cdot 9$ & $41 \cdot 7$ & $68 \cdot 4$ \\
\hline \multirow{2}{*}{\multicolumn{2}{|c|}{ RPCF }} & \multicolumn{3}{|c|}{ Positive, per cent. } & $\ldots$ & . & $54 \cdot 3$ & $55 \cdot 2$ & $65 \cdot 7$ & $44 \cdot 9$ & $59 \cdot 7$ & $38 \cdot 8$ \\
\hline & & \multicolumn{3}{|c|}{ Negative, per cent. } & . & . & $45 \cdot 7$ & $44 \cdot 8$ & $34 \cdot 3$ & $55 \cdot 1$ & $40 \cdot 3$ & $61 \cdot 2$ \\
\hline
\end{tabular}

* All weakly reactive and reactive tests have been regarded as positive. For simplicity the few anticomplementary RPCF results have been regarded as negative. 
RPCF test must have been more likely to detect, could be found for the similarity of the results in the VDRL test and the remarkable differences in those of the RPCF test at the two schools.

All our subjects were aged from 35-64 years and came from lower socio-economic groups. The prevalence in younger Jamaicans will be less because many will never have been exposed to yaws the incidence of which has now dramatically declined. Young people and children are also less likely than adults to be infected with syphilis. Jamaicans in higher socio-economic groups are also less likely to be sero-reactive because yaws is a disease of the underprivileged. Urquhart and Grant (1965) found that only 3.8 per cent. of 132 Jamaican nurses and students were reactive in the RPCF test. It must also be remembered that Lawrence Tavern is a rural area where the incidence of yaws was previously high; a similar survey in other areas might not show the same prevalence of seroreactivity.

Although a positive serolo $;$ i al test in a Jamaican rarely indicates active disease, it may cause considerable inconvenience and distress. A positive test used to preclude acceptance as farm labourers in the United States. Some applicants seek treatment from a series of doctors and as the test remains positive suffer much disappointment and expense they can ill-afford.

A frequent problem is the advisability of treating patients who are sero-reactive but show no signs of yaws or syphilis. The usual course of action is to give penicillin; luckily there have been few serious reactions to this very widely-used antibiotic.

The pattern of treponemal infection in Jamaica and in other parts of the West Indies needs elucidating, but the position is changing very rapidly. Yaws has been virtually eradicated, so that a new generation will be growing up which may be exposed to syphilis without having had previous yaws infection. In addition, the treatment of syphilis has been so changed by the introduction of penicillin that the incidence of tertiary syphilis has been reduced and the appearances of this stage, if it does occur, may be altered.

\section{Summary}

VDRL and RPCF tests were carried out on representative samples of about 500 subjects aged 35-64 years living in a rural area of Jamaica where yaws was once common, and in about the same number of subjects in a suburban community where yaws transmission very rarely occurred; some people had, however, spent their childhood in rural areas.
The proportion of reactors was high; 40 per cent. by the VDRL and 50 per cent. by the RPCF tests were reactive in the rural area; 34 per cent. by the VDRL and 38 per cent. by the RPCF were reactive in the suburban community. The reactivity of those who were born and brought up in the suburban community was lower ( 16 and 24 per cent. by the VDRL and RPCF tests respectively) than that of those who had spent their childhood in rural areas before migrating to the city. These differences are attributed to the prevalence of yaws infection acquired in childhood in rural areas; although the disease had been cured, sero-reactivity persisted.

The rapidly changing pattern of treponemal infection and the difficulties involved in interpreting serological tests in Jamaica are briefly discussed.

We thank Dr A. R. Brathwaite, Senior Medical Officer, Ministry of Health, Jamaica, for information on attendance at clinics.

\section{REFERENCES}

Ashcroft, M. T., Urquhart, A. E., and Gentle, G. H. K. (1965). Trans. roy. Soc. trop. Med. Hyg., 59, 649.

Blake, J. (1961). "Family Structure in Jamaica". Free Press of Glencoe, New York.

Chambers, H. D. (1937). Trans. roy. Soc. trop. Med. Hyg., 31, 245.

(1938). "Yaws (framboesia tropica)". Churchill, London.

Clarke, E. (1957). "My Mother who Fathered Me". Allen and Unwin, London.

Cruickshank, E. K. (1956). W. Indian med. 7., 5, 147. , Montgomery, R. D., and Spillane, J. D. (1961). Wld Neurol., 2, 199.

Foder, J., Miall, W. E., Standard, K. L., Fefjar, Z., and Stuart, K. L. (1964). Bull. Wld Hlth Org., $31,321$.

Gentle, G. H. K. (1965). Brit. F. vener. Dis., 41, 155.

Gourlay, R. J., and Marsh, M. (1965). Amer. F. trop. Med. Hyg., 14, 777.

Grant, L. S. (1956). W. Indian med. F., 5, 97.

Henriques, F. (1957). "Jamaica, Land of Wood and Water". MacGibbon and Kee, London.

Hudson, E. H. (1965). Bull. Wld Hlth Org., 32, 735.

Kumm, H. W. (1935a). Ann. trop. Med. Parasit., 29, 283.

- (1935b). Trans. roy. Soc. trop. Med. Hyg., 29, 265. and Turner, T. B. (1936). Amer. F. trop. Med., $16,245$.

$\longrightarrow,-$, and Peat, A. A. (1935). Ibid., 15, 209.

Montgomery, R. D. (1960). W. Indian med. f., 9, 244. Cruickshank, E. K., Robertson, W. B., and McMenemey, W. H. (1964). Brain, 87, 425.

Rodgers, P. E. B. (1965). W. Indian med. F., 14, 36.

Saunders, G. M., Chambers, H. D., and Rerrie, J. I. (1936). "Annual Report of the Jamaica Yaws Commission for 1936". Kingston, Jamaica.

-, Kumm, H. W., and Rerrie, J. I. (1936). Amer.F. Hyg., 23, 558.

Stuart, K. L., Miall, W. E., Tulloch, J. A., and Christian, D. E. (1962). Brit. Heart $\mathcal{F}$., 24, 455.

Tulloch, J. A. (1958). W. Indian med. F., 7, 169. 
Turner, T. B. (1930). Bull. Fohns Hopk. Hosp., 46, 159. (1936). Amer. F. Hyg., 23, 431. and Saunders, G. M. (1935). Ibid., 21, 483.

U. S. Communicable Disease Center (1962). "Laboratory Procedures for Modern Syphilis Serology", Public Health Service Publication No. 988.

Urquhart, A. E., and Grant, L. S. (1965). W. Indian med. F., 14, 22.

Les tests sérologiques chez les adultes de deux communautés de la Jamaique atteints de maladies causées par des tréponèmes

Résumé

Les tests VDRL et RPCF ont été faits sur des groupes représentatifs d'à peu près 500 habitants âgés de 35 à 64 ans d'une région rurale de la Jamaïque où le pian était auparavant fréquent, et sur à peu près le même nombre d'habitants d'une région suburbaine où la transmission du pian avait rarement eu lieu; cependant quelqu'uns de ces derniers avaient passé leur enfance dans des régions rurales.

La proportion des habitants donnant une réaction positive était élevée; $\mathbf{4 0}$ pour cent positifs au VDRL et 5 pour cent au RPCF dans la région rurale; 34 pour cent au VDRL et 38 pour cent au RPCF chez la communauté suburbaine. Ceux qui étaient nés et avaient vécu dans la communauté suburbaine montraient une réaction plus basse que ceux qui avaient passé leur enfance dans une région rurale avant d'aller habiter une ville ( 16 pour cent et 24 pour cent aux tests VDRL et RPCF respectivement). Ces différences sont attribuées au fait que le pian avait été contracté pendant l'enfance passée dans les régions rurales et malgré que la maladie avait été guerie la réaction du sérum avait persisté.

La rapidité du changement dans le cours de l'infection causée par les tréponèmes et les difficultés crées au sujet de l'interprétation des tests sérologiques à la Jamaïque sont brièvement discutées. 